\title{
On the Right to Have Nationality Rights: Statelessness, Citizenship and Human Rights
}

\section{David Owen ${ }^{1}$}

Published online: 30 November 2018

(C) The Author(s) 2018

\begin{abstract}
This article considers contemporary predicaments of nationality rights against the background of reflection on Arendt's phrase 'the right to have rights'. Addressing the right to a nationality, the right not to be arbitrarily deprived of one's nationality, the right to change one's nationality and the right to naturalize, it argues that Arendt's concerns remain live ones for us and indicates what conception of the institution of citizenship and what conception of international order would serve to realize a right to have nationality rights.
\end{abstract}

Keywords Arendt $\cdot$ Rights $\cdot$ Nationality $\cdot$ Citizenship $\cdot$ Statelessness $\cdot$ Arbitrary deprivation $\cdot$ Naturalize

The fundamental deprivation of human rights is manifested first and above all in the deprivation of a place in the world which makes opinions significant and actions effective. [...] We became aware of the existence of a right to have rights (and that means to live in a framework where one is judged by one's actions and opinions) and a right to belong to some kind of organized community, only when millions of people emerged who had lost and could not regain these rights because of the new global political situation.

Hannah Arendt, The Origins of Totalitarianism (1958)

\section{Introduction}

With the post-war development of the international human rights regime, especially since the mid-1970s, the sceptical remarks of Hannah Arendt's concerning human rights in the context of statelessness, her provocative claim that national citizenship

David Owen

dowen@soton.ac.uk

1 School of Economic, Social and Political Sciences, University of Southampton, Southampton, UK 
was a condition of meaningful possession of human rights, and her tantalising invocation of 'a right to have rights' may seem as if they belong to an era that has been superseded by these developments. ${ }^{1}$ Although the development of the international human rights regime began slowly and was only in its earliest days at the point that Arendt's reflection were written, it accelerated from the mid-1970s not least because of the efforts of nongovernmental organisations which, in coalition with smaller democracies, significantly contributed to 'the institutionalization of legally binding accountability structures over the course of the 1980s and $1990 \mathrm{~s}^{2}{ }^{2}$ However, despite 'the momentous development of the international system for protection of human rights since World War II, the citizenship of a person determines how she is treated by this system; the rights people effectively have are still generally determined with a reference to the country they belong to' ${ }^{3}$ In this context, the challenge of Arendt's reflections on statelessness, citizenship and human rights remains salient, and although my concern in this essay is not with the interpretation of Arendt, the central topic that I do address may be seen, I hope, as responding to the spirit of her enquiry. This topic is the predicaments of nationality rights in our contemporary political context (where this encompasses the right to a nationality, the right not to be arbitrarily deprived of one's nationality, the right to change one's nationality and, relatedly, what we may term 'the right to naturalisation'). I take up this topic because central to the post-war response to the condition addressed by Arendt was the focus on securing human rights to possession, maintenance and change of nationality. Here it may be helpful to cite a remark of Arendt's:

Equality, in contrast to all that is involved in mere existence, is not given us, but is the result of human organization insofar as it is guided by the principle of justice. We are not born equal; we become equal as members of a group on the strength of our decision to guarantee ourselves mutually equal rights. Our political life rests on the assumption that we can produce equality through organization, because man can act in and change and build a common world, together with his equals and only with his equals. ${ }^{4}$

\footnotetext{
${ }^{1}$ These developments would include the development of UN Charter-based system for supporting human rights, but perhaps more significantly the UN treaty-system which began with the International Convention on the Elimination of All Forms of Racial Discrimination (1965), followed by the International Covenant on Civil and Political Rights and the International Covenant on Economic, Social and Cultural Rights (ICESCR) in 1966, before focusing on less generic themes and groups such as the Convention on the Elimination of All Forms of Discrimination against Women (1979); the Convention against Torture and Other Cruel, Inhuman or Degrading Treatment or Punishment (1984); the Convention on the Rights of the Child (1989); the International Convention on the Protection of the Rights of All Migrant Workers and Members of Their Families (1990); and the Convention on the Rights of Persons with Disabilities (2006). With the adoption of an Optional Protocol to ICESCR in 2008, the UN treaty system aims to uphold the principle that all rights are justiciable. To this can be added regional developments such as the European Convention on Human Rights and the European Court of Human Rights to take the most developed example.

${ }^{2}$ Simmons (2009), p. 51.

${ }^{3}$ Bauböck and Paskalev (2015), p. 49.

${ }^{4}$ Arendt (1958), p. 301.
} 
Her comment is directed at political life within states, but the point has general application. My starting point is the presumption that becoming equal members of global political society, organising the equal political standing of individuals in an international order of self-ruling territorial states, requires constructing the right to have nationality rights - and my focus in this essay on the predicaments of nationality rights is concerned to address how we currently stand to such a rightful condition. I adopt the phrase 'the right to have rights' in order to highlight the point that merely to be allowed or permitted to have nationality rights at the discretion of states or, more generally, of the international order of states is precisely not to have a right to such rights. This is, as will we see, an issue of considerable contemporary significance and one that directly implicates the legitimacy conditions of the international order of states as a way of organising global political society.

The essay proceeds as follows. I begin by addressing the right to a nationality in which my focus is on addressing de jure statelessness (Sect. 2) and the right not to be arbitrarily deprived of one's nationality in which I concentrate on denationalisation policies (Sect. 3). I then turn to the topic of de facto statelessness and, more generally, the issue of the right to acquire a new nationality (Sect. 4), before concluding by considering the conditions of a right to have nationality rights.

\section{On the Right to a Nationality}

To take up the issue of the right to have the right to a nationality, we can address statelessness in the de jure sense is specified by Article 1 of the 1954 Convention Relating to the Status of Stateless Persons: "the term "stateless person" means a person who is not considered as a national by any State under the operation of its law'. Such statelessness, as the lack of an effective nationality, is both a wrongful condition and a harmful condition. It is a wrongful condition because it represents a failure to secure the fundamental right of individuals to political standing in global political society organized as international order of states. To put the point another way, we can note that the phenomenon of de jure statelessness represents a legitimacy problem for the international order of states. It does so precisely because it is a legitimacy condition of any political order (and, hence, the international order of states) that those who are subject to its rule have political standing in relation to this rule; this is a necessary condition of a political order being an order of right rather than might, of that order giving rise to political obligations rather than being simply a structure of coercively-enforced commands. At the same time, statelessness is a harmful condition because it exposes individuals to radical insecurity in terms of access to rights and resources; it leaves them highly vulnerable to arbitrary exercises of private and public power. Precisely because citizenship has both protective and enabling dimensions, possession of an effective nationality acts as gateway to a range of liberties, resources and powers - and the lack of an effective nationality obstructs access to these protective and enabling conditions of autonomy and well-being. Today, this duality of statelessness as both wrong and harm is widely recognized. 
The opening article of the 1930 Hague Convention on Certain Questions Relating to the Conflict of Nationality Laws registered the need for a nationality, stating 'that every person should have a nationality and should have one nationality only'. In the postwar period, Article 15(1) of the 1948 UN Declaration of Human Rights (UNDHR) states that 'Everyone has the right to a nationality', while Article 24(3) of the 1966 International Covenant on Civil and Political Rights (ICCPR) which entered into force in 1976 states: 'Every child has the right to acquire a nationality.' The period between the UNDHR and the ICCPR saw the emergence of the 1954 Convention Relating to the Status of Stateless Persons ${ }^{5}$ and the 1961 Convention on the Reduction of Statelessness ${ }^{6}$ designed to address and resolve the problem of de jure statelessness. ${ }^{7}$ These developments can be seen as representing the juridical elements in the political project of constructing the right to have the right to a nationality.

Before we turn to explore how de jure statelessness arises and its implications for our concerns, however, we should briefly consider the concept of having an 'effective nationality'. In the 'Prato Conclusions' summarising the outcomes of a 2010 UNHCR expert meeting on the Concept of Stateless Persons under International Law, it was noted:

For the purposes of the 1954 Convention, 'national' is to be understood by reference to whether the State in question regards holders of a particular status as persons over whom it has jurisdiction on the basis of a link of nationality. Several participants were of the view that in practice it is difficult to differentiate between the possession of a nationality and its effects, including, at a minimum, the right to enter and reside in the State of nationality and to return to it from abroad, as well as the right of the State to exercise diplomatic protection. Otherwise, according to this view, nationality is emptied of any content. ${ }^{8}$

\footnotetext{
5 The 1954 Convention is designed to ensure that stateless people enjoy a minimum set of human rights. It establishes the legal definition of a stateless person. The 1954 Convention also establishes minimum standards of treatment for stateless people in respect to a number of rights. These include, but are not limited to, the right to education, employment and housing. Importantly, the 1954 Convention also guarantees stateless people a right to identity, travel documents and administrative assistance. There were 83 states party to the 1954 Convention in November 2014 when teams at the United Nations High Commissioner for Refugees (UNHCR) launched the Campaign to End Statelessness in 10 years. There are now 89-compare 154 to the 1951 Refugee Convention.

${ }^{6}$ The 1961 Convention aims to prevent statelessness and reduce it over time. It establishes an international framework to ensure the right of every person to a nationality. It requires that states establish safeguards in their nationality laws to prevent statelessness at birth and later in life. Perhaps the most important provision of the convention establishes that children are to acquire the nationality of the country in which they are born if they do not acquire any other nationality. It also sets out important safeguards to prevent statelessness due to loss or renunciation of nationality and state succession. The convention also sets out the very limited situations in which states can deprive a person of his or her nationality, even if this would leave them stateless. There were 61 states party to the 1961 Convention in November 2014 when teams at UNHCR launched the Campaign to End Statelessness in 10 Years. There are now 67.

${ }^{7}$ For an important recent analysis of the implementation of the 1954 Convention in the European Union, see Bianchini (2018).

${ }^{8}$ UNHCR (2010), para. B7.
} 
De jure statelessness is the condition of lacking an effective nationality where possessing an effective nationality requires not only access to civic rights within the territory of one's state of nationality but crucially also these rights of entry, resident and diplomatic protection. The right to entry and residence is primary here since to possess civic rights in a given place, one has to have the freedom to be in (or return to) that place.

The sources of relevant forms of de jure statelessness can be structural or administrative. ${ }^{9}$ Structural statelessness arises, fundamentally, from the fact that states have the right to determine their own citizenship laws and that the laws that they adopt may leave some persons lacking a nationality. The two primary modes for our current concern are, first, 'conflict of laws' such as the case that of a person born in a state with a pure ius sanguinis rule to parents who are non-citizen immigrants from a state with a pure ius soli rule and, second, the transfer of territory or sovereignty which alters the nationality status of citizens of the former state(s) and may leave some persons stateless (this arose, for example, with the break-up of the Soviet Union, Yugoslavia and Czechoslovakia). Administrative statelessness arises from the fact that applications for nationality require documents and that such documents are produced and processed by administrative agencies and officers of states. Perhaps the most important of such documents, and the one I will focus on to illustrate the general point, is the registration of birth:

Birth registration is usually fundamental to the realisation of all other citizenship rights: lack of birth certificates can prevent [presumptive] citizens from registering to vote, putting their children in school or entering them for public exams, accessing healthcare, or obtaining identity cards, passports, or other important documents. ${ }^{10}$

In 2017 UNICEF reported that 'the births of around one fourth of children under the age of five worldwide have never been recorded'. ${ }^{11}$ In sub-Saharan Africa, that figure rises to just over $50 \%{ }^{12}$ This issue can also be particular significant in contexts of refugee flight from conflict. As David Howard note in the context of the current Syrian crisis:

One of the many problems Syrian refugees face is statelessness. Children of refugees from countries such as Syria can often be born stateless, as the child is born outside the parent's country, and nationality laws do not allow the mother's citizenship to be passed to the child. Additionally, the parents may be unable to bring documentation from Syria, making it difficult to register the birth of their child in another country. Without such documentation, the child may never be registered and thus may be denied access to basic services, including healthcare. While lacking documentation alone does not make a

\footnotetext{
9 For a detailed list, see ISI (2018) and for discussion see Van Waas (2009).

10 Manby (2009), p. 115.

11 UNICEF (2017a).

12 UNICEF (2017b).
} 
child stateless, without proof of birth or identity of parents, the child has a significantly higher risk of being stateless. ${ }^{13}$

In the European Union, administrative statelessness is a particular problem for the Roma, notably in the post-Yugoslavia states. ${ }^{14}$ Relevant forms of what I am calling 'administrative statelessness' may arise from the lack of state administrative capacity (especially in rural areas), administrative or procedural problems (such as excessive fees, unrealistic deadlines, lack of appeal or review procedures, etc.), administrative corruption (e.g., the need for bribes to get documents processed), or as a product of refugee flight or irregular migration.

One reason for distinguishing structural and administrative sources of de jure statelessness is that they draw our attention to different dimensions of what constructing the right to have the right to a nationality requires ranging from issues of capacity, disposition and norms in the administrative practice of the state to governmental conceptions of national political community to the normative ordering of global political society. It is against this background that we can briefly consider the \#IBelong campaign launched by the UNHRC in 2014 to mark the 60th anniversary of the 1954 Convention with the ambitious aim of ending de jure statelessness within 10 years. While it is, unsurprisingly, unclear how many people are de jure stateless (both for reasons pertaining to who gets counted within the definition and for reasons pertaining the problems of counting), estimates that are acknowledged likely to be conservative place the figure in the region of 10-15 million (of which 3 million are estimated to be children). ${ }^{15}$ An early positive sign for this campaign came in West Africa in 2015 as the fifteen ECOWAS Member States adopted the landmark Abidjan Declaration in February 2015, recognizing statelessness as a scourge in the region and committing to end this phenomenon by 2024 , with the 2017 Plan of Action laying out concrete measures aimed at addressing the causes of statelessness by rectifying gaps in nationality laws and issues relating to proof of nationality. ${ }^{16}$ If successful, this would not be not a trivial result but one that combines a focus on technical issues relating to legal rules and administrative capacity with supporting a more inclusive approach to political community at least within the region. However, while the energy and attention directed by this campaign towards statelessness is welcome and can be seen as supporting the more robust construction of a right to nationality, we should be wary of imagining that the problem of de jure statelessness can be easily addressed in a global political context in which non-compliance with the international norm against de jure statelessness may serve government's political purposes. This point will be to the forefront in the next section addressing citizenship deprivation, but it also has salience here in terms of the political will to acknowledge or redress the problem of statelessness.

\footnotetext{
${ }^{13}$ Howard (2017), p. 284.

${ }^{14}$ See Sardelic (2015) and Bianchini (2018), pp. 59-61.

15 ISI (2014).

${ }^{16}$ ECOWAS (2017).
} 
To illustrate this point, consider two types of example. The first is a policy of creating difficulties for members of particular ethnic groups to obtain a nationality to which they are entitled. As Bronwen Manby notes of Africa: 'In practice, individual Africans far more often face the practical impossibility of obtaining official documentation than an explicit legal denial of nationality'. ${ }^{17}$ Stories of the difficulty of obtaining, for example, passports are widespread in African states and typically exhibit an ethnically patterned character. ${ }^{18}$ It is worth noting the example of Kenya since, in this state, the value of a birth certificate is undermined by the fact that the certificate explicitly state that it has no standing with respect to nationality determination. In the quest for identity cards or passports, which are necessary to vote, 'Kenyan Somalis, Nubians and others faced demands for bribes of complete refusal to grant documentation'. ${ }^{19}$ Similar difficulties are confronted by the Roma in Europe. ${ }^{20}$ The second type of example is a state practice of responsibility-avoidance that construes the constraint of complying with international norms governing the reduction of de jure statelessness in such a way as to avoid its effective operation and is also salient in relation to the UNHCR's current campaign. This example is drawn from research in Malaysia conducted by Catherine Allerton who notes the UNHCR campaign focuses on measures such as 'birth registration and the reform of nationality laws, in particular, so that otherwise stateless children can acquire the nationality of the state in which they were born' ${ }^{21}$ before remarking:

In Malaysia, it would seem that no such legal reform is needed. Although the country subscribes to a jus sanguinis principle of citizenship, there are clear legal provisions to protect the status of otherwise stateless children. The federal constitution allows for a child born in Malaysia, who is 'not born as citizen of another country', and who cannot acquire citizenship of another country by registration within 1 year of birth, to become a citizen of Malaysia by operation of law. However, in reality, Malaysian citizenship has never been granted to a child on such terms. ${ }^{22}$

Allerton's point is that in contexts such as Malaysia what is fundamentally at issue is not the letter of the law but the practice of the law which appears, under its operation, to be designed both to avoid the responsibility that arises with the recognition of a child as de jure stateless and in doing so to support a particular and exclusive conception of Malay national community.

The entanglement of statelessness, nationality rights and governmental conceptions of national community will be a recurring theme in this essay and points to a central issue for the question of the right to have the right to a nationality, namely, that establishing the right to have the right to a nationality is not simply a matter of

${ }_{17}$ Manby (2009), p. 115.

${ }^{18}$ See Manby (2009), pp. 116-117.

19 Manby (2009), p. 120.

${ }^{20}$ Sardelic (2015).

${ }^{21}$ Allerton (2017), p. 250.

${ }^{22}$ Allerton (2017), pp. 250-251. 
building the capacities and dispositions of states or even of encouraging more inclusive and pluralistic conceptions of political community, but of establishing institutions and practices that can effectively contest state practices and judgments where this means that the international order of states recognizes that it is accountable to individuals for the condition of de jure statelessness. To address the form of this accountability, however, requires not merely an effective norm against de jure statelessness, but an account of the point and purpose of the institution of citizenship in a global political society organised as an international order of states. To put the point hyperbolically, the problem of de jure statelessness could be formally resolved by a global citizenship lottery in which, at birth, each individual was randomly allocated a state nationality. Yet this would not be a solution in anything other than a notional formal sense, rather what is needed is a normative conception of the institution of state citizenship that identifies which persons have legitimate claims to membership of which state. To see this point, consider how Allerton illustrates her point that Malaysia, in the practice of its law, avoids the norm against de jure statelessness:

For example, in a 2015 case, a Malaysian father's application for citizenship for his 5-year-old son was rejected. Since the parents were not married at the time of the boy's birth, the judge stated that the boy should follow his birth mother's nationality. The fact that the boy's mother was a Thai national, who disappeared when he was 6 months old and has never been tracked down, was deemed irrelevant. The judge ruled that the boy (who had lived all his life in Malaysia) could apply for Thai citizenship and was therefore not a stateless child. $^{23}$

If we abstract this case from the generalised context of restricting access to citizenship in which it is embedded and accept that the child could apply for Thai citizenship under the practice of Thai law, the question that arises is why Malaysia has a responsibility to admit this child to citizenship, that is, why this child has a legitimate claim to Malaysian nationality. The answer to this question is not given simply by an international norm against de jure statelessness. I will take up this question of the claim not simply to $a$ nationality but to this nationality in the next section within the high stakes context of citizenship deprivation.

\section{On the Right not to be Arbitrarily Deprived of One's Nationality}

For individuals who have acquired an effective nationality, the key issue becomes that of their right to this nationality, that is, their right not to be arbitrarily deprived of it. Our focus in this section thus addresses the conditionality of citizenship and will focus on two types of example: mass denaturalisation and individual denaturalisation.

${ }^{23}$ Allerton (2017), p. 251. 
Examples of mass denaturalisations by modern states are readily available. The ongoing case of the Rohingya in Myanmar has been rightly highlighted, ${ }^{24}$ however, I'll focus on the example provided by the Dominican Republic in its treatment of people of Haitian descent not least because it is a reasonably established (albeit flawed) constitutional democracy and because the policy in question has been subject to both judicial and legislative judgment within the state. Consider the following case:

Dilcia Yean was born on April 15, 1996, in the Dominican Republic to a Dominican woman of Haitian descent. Although the Dominican constitution establishes the principle of jus soli (and thus assigns citizenship to those born on Dominican territory), Yean was denied Dominican citizenship, and was refused permission to register her birth or to obtain recognition of her legal personality. Government officials said they had orders not to register or issue birth certificates to children of Haitian descent. ${ }^{25}$

The situation of Dilcea Yean was subject to judicial review by the Inter-American Court of Human Rights which upheld the right to registration of persons in her situation. ${ }^{26}$ But the political effect of this judgment was to escalate the issue further:

In 2013, the Constitutional Court's judgment 168/13 established that only persons born in the Dominican Republic to Dominican parents or legal residents are consider citizens. This interpretation was applied retroactively to all persons born between 1929 and 2010: arbitrarily depriving hundreds of thousands of people of Haitian descent, of their Dominican nationality, and created a situation of statelessness of a magnitude never before seen in the Americas. The criterion established in judgment 168/13, as well as the measures adopted to implement that judgment, come to constitute a crucial stage in this type of historical revisionism promoted by the Dominican authorities, aimed at consolidating an interpretation that establishes that persons born in the Dominican Republic of Haitian parents with an irregular migratory status do not have the right to Dominican nationality. ${ }^{27}$

This ruling, which was rapidly condemned by the Inter-American Commission on Human Rights, ${ }^{28}$ is estimated to have affected over 200,000 people. It was followed by action from the legislature in the form of the Naturalisation Law of 2014 which claimed to provide a route to, or back to, citizenship for those affected (86\% of these being of Haitian descent) but placed the burden of proof on individuals to provide

\footnotetext{
24 UNHCR (2017).

25 Goldston (2006), p. 321.

26 The full judgment can be found here: http://www.corteidh.or.cr/docs/casos/articulos/seriec_130_\%20 ing.pdf (accessed 23 Jul 2018).

27 IACHR (2015).

28 IACHR (2015).
} 
the very documentation that many had been denied within overly demanding deadlines. ${ }^{29}$ As a report for the Brookings Institute notes:

Records, while not completely reliable, show that up to 7000 people were able to regularize their status before the expiration of a June 2015 moratorium. Those who were unable to regularize their status were required to register as foreigners in the country where they were born. Many of the affected had never seen Haiti but between August 2015 and May 2016 - after the expiration of the June 2015 moratorium-it was estimated that over 40,000 people were deported from the Dominican Republic to Haiti. A further 71,389 people reportedly returned 'spontaneously'. 30

The Dominican Republic is, of course, not alone in engaging in such practices and the emerging situation concerning citizens of Bangladeshi descent in Indian state of Assam may become another such example. ${ }^{31}$ Whether or not such actions do give rise to significant numbers of de jure stateless persons (as they have in the case of the Rohingya) is contingent on the laws and actions of other states (for example, Haiti in the case of the Dominican Republic); what is important about the case of the Dominican Republic is that due legal process was followed. Does it then represent an example of breach of the right not to be arbitrarily deprived of one's nationality expressed in Article 15(2) of UNDHR - and one in which the norm against de jure statelessness is simply ignored with little in the way of effective constraint?

The second example is that of individual denaturalisation-and my focus here will be on the return of denaturalization policies in the context of the 'War on Terror' ${ }^{32}$ This example is particularly salient to our concern because

the impact of the enhanced protection of democracy and human rights within Western States in the second part of the 20th century on citizenship was profound and seemed to transform it from a privilege bestowed by a sovereign government on those who were worthy of it, into an entitlement of the sovereign citizen, whose status as such cannot be altered by the government. ${ }^{33}$

Thus, for example, Matthew Gibney notes: 'By the end of the 20th century, deprivation power in the UK appeared to be moribund. By 2002, not a single individual had lost his or her citizenship (other than under fraud provisions) for 30 years' ${ }^{34}$ It is just this apparent transformation that is challenged by the return of denationalisation policies within these 'Western States'. As Audrey Macklin remarks:

the force of Arendt's 'right to have rights' aphorism may seem attenuated, at least with respect to liberal democratic states of the twenty first century. After all, permanent residents enjoy almost all the same rights as citizens, and even

\footnotetext{
${ }^{29}$ Young (2017).

${ }^{30}$ Young (2017).

${ }^{31}$ Khalid (2018).

${ }^{32}$ For particularly important work, see Gibney $(2013,2014,2017)$ as well as Macklin (2015).

${ }^{33}$ Bauböck and Paskalev (2015), p. 50.

${ }^{34}$ Gibney (2014), p. 330.
} 
foreigners without status can, in principle, claim a long menu of basic human rights under international law and many domestic legal orders. But this rejoinder overlooks one crucial fact. The exercise of virtually all rights depends on territorial presence within the state, and only citizens have an unqualified right to enter and remain on state territory. So once stripped of the right to enter and remain in the state, enforcement means that one is effectively deprived of all the other rights that depend (de jure or de facto) on territorial presence. ${ }^{35}$

As pioneer in this area, the UK serves as an appropriate example. ${ }^{36}$ Thus, the Nationality, Immigration and Asylum Act 2002 introduced a general power for the Home Secretary to deprive a person of their citizenship status if satisfied that this person had acted in ways seriously prejudicial to the vital interests of the UK, where for the first time this power applied to birthright as well as naturalized citizens, but where the power would not apply if deprivation would make the person de jure stateless. This criterion was further altered in section 56 of the Immigration, Asylum and Nationality Act 2006 to that of allowing deprivation if this is 'conducive to the public good'. Denaturalisation policy was further extended in the Immigration Act 2014 in which dual citizens remained subject to the 2006 criterion, but naturalized citizens currently possessing only UK nationality were subject to a new standard in which they could be deprived of citizenship if:

(a) the Secretary of State is satisfied that the deprivation is conducive to the public good because the person, when a British citizen, 'has conducted him or herself in a manner which is seriously prejudicial to the vital interests of the United Kingdom' or associated territories; and (b) the Secretary of State has 'reasonable grounds for believing that the person is able, under the law of a country or territory outside the United Kingdom, to become a national of such country or territory, ${ }^{37}$

This is held to be compatible with the UK's international obligations. ${ }^{38}$ From 2011 to 2015, following due legal process, 72 UK citizens were stripped of their citizenship.

The fundamental issue raised by the cases of the Dominican Republic and the UK, given that in both cases the denaturalisation practices introduced complied with the normal standards of due legal process in these states, concerns what constitutes an arbitrary deprivation of one's nationality. This question has particular purchase today since our situation is complicated by the relative collapse of the norm of single nationality which facilitates citizenship deprivation insofar as the state's exercise of this power does not entail breaching the norm against de jure statelessness.

\footnotetext{
${ }^{35}$ Macklin (2014), p. 2.

${ }^{36}$ For an overview, see McGuinness and Gower (2017) and Anderson (2016).

37 Anderson (2016), p. 3.

38 Anderson (2016), p. 5.
} 
We can begin to approach these issues by noting two contrasting - and equally inadequate-views of entitlement to citizenship. The first is clearly expressed by the UK:

[It] regards the sovereign power of states to determine their own citizens not merely as a principle of international law that applies in relations with other states but also as an element of their internal democratic self-determination. State discretion therefore primarily means legislative discretion. A democratically legitimate legislature should be broadly free to set the rules not only for citizenship acquisition but also for deprivation in accordance with its political goals and in a way that it considers conducive to the public good, within constraints of constitutional and international law that the legislature has itself freely accepted. ${ }^{39}$

The second contrasting conception

considers citizenship as an individual entitlement that is held against the State and thus limits the scope of the State's deprivation powers. The underlying normative view is to think of citizenship as a foundation of individual autonomy analogous to individual property that the State must protect and of which it cannot deprive its citizens without losing legitimacy. ${ }^{40}$

Whereas the first view assigns discretionary power to the state, the second view ascribes it to the individual. What both views fail to recognize is that the normative point of the institution of state citizenship in an international order of plural selfruling states is not simply to allocate persons to states on the basis of unilateral state choices or unilateral individual choices but on the basis of a reciprocal relationship between individuals and states.

To see this point, let us step back from the issue of citizenship deprivation for the moment to address a prior question: 'what do we need state citizenship rules for?' In a global political society organised as an international order of plural autonomous states, there are two basic functions that such rules are to play:

1. to ensure that each and every human being is a citizen of a state and hence that everyone has, at least formally, equal standing in a global society organised as a system of states;

2. to link persons to states in ways that best serve the common interest, that is, where this supports protection of the fundamental interests of individuals, the realization of the common good within states, and the conditions of cooperation between states.

An appropriate general response to these requirements is the principle that Ayelet Shachar calls 'ius nexi' which highlights the importance of a genuine connection

39 Bauböck and Paskalev (2015), pp. 62-63.

40 Bauböck and Paskalev (2015), p. 63. 
between persons and the state of which they are citizens, ${ }^{41}$ where the notion of 'genuine connection' is best glossed in terms of Bauböck's 'citizen stakeholder' view which proposes that those and only those individuals have a claim to membership of a polity whose individual autonomy and wellbeing is linked to the collective selfgovernment and flourishing of that polity. ${ }^{42}$ On this view, we should see particular citizenship rules such as ius soli, ius sanguinis and ius domicilii as denoting different routes through which a genuine connection is presumptively establishedthrough parental citizenship, through place of birth and through residence-and as subject to the general principle of ius nexi. As Bauböck and Paskalev note, such a normative conception of citizenship 'needs to be interpreted broadly in a way that takes into account some basic and normatively justifiable features of this system' such as 'birthright attribution of citizenship, individual consent in naturalization and renunciation, the prevention of statelessness, and normative commitments to peaceful and friendly international relations'. ${ }^{43}$ If we return to Allerton's 2015 Malaysian case, noted in the preceding section, of a 5 year old child who had lived his whole life in Malaysia with his Malaysian father, the boy's Thai national mother having abandoned the family when he was 6 months old, then on this 'ius nexi' view of citizenship the child has a legitimate claim to Malaysian nationality and does so irrespective of whether he also has a legitimate claim to Thai nationality.

The implications of such a 'citizen stakeholder' view for contexts of mass denaturalization are twofold. First, it holds that 'individuals are subject to arbitrary political domination if they have genuine links to the political community' but are 'involuntarily excluded from citizenship'. ${ }^{44}$ This point applies to those who are prevented from acquiring citizenship such as the ethnic minorities in Kenya highlighted in the last section and people of Haitian descent in the Dominican Republic such as Dilcea Yean as well as people who are deprived of citizenship as members of a social group such as those whose citizenship was removed through the 2013 Dominican Supreme Court ruling. Second, because statelessness is both a wrong and a harm, it provides sufficient reason to legitimate granting citizenship to individuals whose current autonomy and well-being, extending to basic rights, is vulnerable to the decisions of a state even if they do not already possess established ties to that state. ${ }^{45}$

If we turn to the issue of individual denaturalization, then the salience not only of protection of the fundamental interests of individuals but also the realization of the common good within states and the conditions of cooperation between states becomes salient. Current practices of individual citizenship deprivation in the context of the 'War on Terror' not only reproduce the arguments for, and the features that characterized, the practice of banishment from the 17th to the 19th century but are also subject to the criticisms that led to the abandonment of this practice, primary among them the complaint made by Voltaire that the banishment of criminals

\footnotetext{
41 Shachar (2009).

42 Bauböck (2015).

43 Bauböck and Paskalev (2015), p. 67.

44 Bauböck and Paskalev (2015), p. 67.

45 Bauböck and Paskalev (2015), p. 68
} 
undermines the comity of nations because it is akin to 'throwing into a neighbour's field, the stones that incommode us in our own'. ${ }^{46}$ Moreover, in contexts of presumptive dual nationality that are legitimated as avoiding the creation of statelessness, such denationalization practices simply incentivize a race to denationalization [as the UK case of Pham (previously B2) v. Home Secretary illustrates]. Even if we set these considerations aside, however, a further key point remains, as a recent comment on the UK case makes plain: 'The provision of security is the core function of the State and it has a duty to prosecute and convict those who jeopardize it. By excommunicating them without conviction, the British government is shirking this duty. ${ }^{47}$

Arbitrary deprivation can thus be understood as deprivation that fails to acknowledge the 'genuine link' between a person and a state and the responsibilities that adhere to this relationship within the context of an international order of states. In terms of the right to have a right to not be arbitrarily deprived of one's nationality, it is clear that the establishment of such a right is not compatible with an international order of states in which states have the discretion to determine unilaterally their own citizenship rules and this is so even if this political order is subject to an effective binding norm against de jure statelessness.

\section{The Right to Change One's Nationality and the Right to Naturalize}

The grounds of the human right to change one's citizenship that is expressed in UNDHR Article 15(2) are closely related to the grounds of the human right not to be prevented from leaving the territory of a state. If these rights to exit from the territory or from citizenship are denied, citizens (and residents in the territorial case) are subject to the dominion of the state irrespective of their own choices or circumstances. From a liberal perspective, denying voluntary renunciation that does not render a person stateless is an unjustifiable interference with the free choices of individuals concerning those with whom they choose to engage in civic association. From a republican point of view, it is a political form of servitude in that it leaves citizens exposed to the arbitrary power of the state. In this respect, it is a normatively significant and unjustified feature of global political society that there are a number of states that do not permit voluntary renunciation of citizenship or only permit it for naturalised citizens. This is particularly significant because of the central role that unchosen birthright citizenship plays in securing individuals against statelessness, in providing stability conditions for the distribution of responsibility for people among states, and in supporting inter-generational solidarity within states. ${ }^{48}$ The right to change one's nationality is thus a fundamental right that justifies restrictions on state sovereignty. However, the effective possession of such a right further requires that it

\footnotetext{
46 Gibney (2013), pp. 646-650.

47 Bauböck and Paskalev (2015), p. 72.

48 For a justification of birthright citizenship/nationality in the context of a 'genuine connection' conception of citizenship, see Bauböck (2017).
} 
can, under the relevant conditions of application, be exercised-and, here, the issue of a right to naturalize becomes central to our concerns.

In introducing this issue, we can start by considering de facto statelessness which, under the Prato Conclusions, is characterised thus: 'de facto stateless persons are persons outside the country of their nationality who are unable or, for valid reasons, are unwilling to avail themselves of the protection of that country'. ${ }^{49}$ As the 'Prato Conclusions' go on to note:

Inability to avail oneself of protection may be total or partial. Total inability to avail oneself of protection will always result in de facto statelessness. Persons who are unable to return to the country of their nationality will also always be de facto stateless even if they are otherwise able in part or in full to avail themselves of protection of their country of nationality while in the host country (i.e. diplomatic protection and assistance). On the other hand, persons who are able to return to their country of nationality are not de facto stateless, even if otherwise unable to avail themselves of any form of protection by their country of nationality in the host country. ${ }^{50}$

This passage expresses a clear ranking of the rights that it takes as (minimally) constitutive of the possession of an effective nationality with the right to return and abide in one's state of nationality trumping the right to diplomatic protection. Since the 'Prato Conclusions' acknowledge that refugees are de facto stateless, it follows that mere formal possession of a right to return is not sufficient and it must also be the case that 'unable or, for valid reasons, unwilling' means having valid reasons to reject the formally available option of return. But what is the extent of such reasons? This issue is raised starkly by the current UK and wider EU practice of returning to Afghanistan, adults who came to the UK as child refugees. Setting aside the question of whether the current dangers confronting returnees from the EU to Afghanistan are compatible with legitimate repatriation, ${ }^{51}$ the issue is whether someone who may have little meaningful connection to Afghanistan, although possessing its nationality has valid reasons not to avail themselves of the right to return and, hence, to be seen as de facto stateless. This question can be extended further. Consider a case raised by Catherine Allerton's research on children and statelessness in East Malaysia:

Take 10 year-old Aisyah, a Suluk girl holding an IMM13 card, whose grandparents came to Sabah as refugees in the 1970s. Once, during a discussion with her class about the differences between Sabah and the Philippines, Aisyah told me: 'I don't know anything about the Philippines'. She has no family that she knows of left there, has never been there, and explicitly refuses to discuss it as a place with which she should have any connection. As holders of IMM13 cards, Aisyah and her parents are 'legal', in the sense of being allowed to remain in Sabah. However, they still lack a nationality. Whether or not the

${ }^{49}$ UNHCR (2010), A (2).

${ }^{50}$ UNHCR (2010), C (7).

${ }^{51}$ For appropriate scepticism, Amnesty International (2017). 
government of the Philippines would recognise them as citizens, and notwithstanding the inability of Aisyah and her brothers to attend Malaysian government school, the important point in their case is that they do not want to be Filipino citizens, since they feel they belong in Malaysia. ${ }^{52}$

Is the fact that Aisyah has no sense of any connection to the Philippines, even though she may be entitled to its nationality, sufficient to count as a valid reason for not applying for Filipino nationality? Given that the current constitution of international order grants state's wide discretion concerning who to admit to citizenship, the immediate political stakes of this question are high.

As the preceding discussion of citizenship deprivation established, a norm of state discretion subject to merely to constraint against statelessness is not a legitimate basis for international order. Rather the legitimacy of this political order requires that it acknowledges ius nexi as a basic constitutional principle and, hence, a human right to naturalize under conditions where a person has a genuine link to a state. This follows directly from the point made in the preceding section: "individuals are subject to arbitrary political domination if they have genuine links to the political community but remain involuntarily excluded from citizenship'. ${ }^{53}$ It is particularly important here to note that the forging of such links is not dependent on one's formal migration status, rather, as Joseph Carens has long argued, a sufficient period of residential presence is sufficient for social membership, that is, the establishment of a genuine link. ${ }^{54}$ In this respect, the egalitarian pressures to expand the concept of de facto statelessness are a political artefact of the absence of a human right to naturalize; one that is given urgency by general vulnerability to public and private forms of domination to which migrants, especially irregular migrants, are exposed.

\section{Conclusion: International Political Order and the Right to have Nationality Rights}

In addressing the right to a nationality, the right not to be arbitrarily deprived of one's nationality, the right to change one's nationality and the right to naturalize, the preceding discussion has drawn attention to both the centrality of the right to have nationality rights to equal membership in global political society and to the incompatibility of the right to have nationality rights with an international order structured in terms of a Westphalian view of state sovereignty. It should be noted though that this claim is not in any incompatible with the idea of an international order composed of self-ruling states; on the contrary, I want to conclude by showing that the right to have rights - of which, in any order of plural autonomous polities, the right to nationality rights is a (and plausibly the) fundamental part-is consonant with an international order of states. To do so, I avail myself of a recent position in global

\footnotetext{
52 Allerton (2014), p. 32.

53 Bauböck and Paskalev (2015), p. 67.

${ }^{54}$ For the most recent statement of this view, see Carens (2013).
} 
justice debates articulated by Cecile Laborde and Miriam Ronzoni which they term 'Republican Internationalism' according to which

Rules and institutions [...] must be designed with the republican rationale of protecting free statehood, rather than replacing it with a full-blown cosmopolitan order. This is not a contradiction in terms, as republican freedom (of collective as well as individual agents) is obtained through non-domination rather than non-interference and is therefore compatible, in principle, with deep and extensive regulation. Non-dominated states, especially in a globalised world, are not states that enjoy unqualified Westphalian sovereignty. ${ }^{55}$

The basic ideal is the classic republican view that can be discerned behind Arendt's own reflections, namely, that one can only be free if one is a free person, one can only be a free person in a free state, and that being a free person in a free state requires that one is a citizen of this state. To be free thus requires being a citizen.

However, for a state to be free, it must be internally self-ruling and externally non-dominated. To be internally self-ruling in the membership aspect that concerns us, it must be the case that the citizenry is composed of all and only persons who are entitled to membership and choose (subject to requirement of being a citizen of a state) to acquire or not surrender this status. This is the condition of the legitimate determination of the 'self' of collective self-rule. The relevant ground of entitlement can be derived from the fact that individual freedom and collective freedom are linked in the republican conception. This is given contemporary expression in Bauböck's 'citizen stakeholder' view which proposes that those and only those individuals have a claim to membership of a polity whose individual autonomy and wellbeing is linked to the collective self-government and flourishing of that polity. ${ }^{56}$ To be externally non-dominated in the membership aspect that concerns us, it must be the case that the states' citizenship rules are subject only to general international rules that they are equal participants in shaping and that are designed to ensure that each and every human being is a citizen of a state and to link persons to states in ways that best serve the common interest. Being a self-ruling state is, on this republican view, entirely compatible with a global regime of regulation with respect to permissible state citizenship rules. More particularly, such a regime is a necessary condition of the de jure right to have nationality rights.

Today we remain at some distance from establishing such a rightful condition even in the limited de facto sense that Arendt saw collapsing around her in early twentieth century Europe-and Arendt's concerns with the fragility of our enjoyment of human rights, their dependence on secure nationality rights, remains a very live concern for us.

Acknowledgements I am grateful to Catherine Allerton for discussion of her research on stateless children in Sabah, and to the referees and editors of NILR for their helpful comments on an earlier draft.

55 Laborde and Ronzoni (2016), p. 281.

56 See Bauböck $(2015,2017)$. 
Open Access This article is distributed under the terms of the Creative Commons Attribution 4.0 International License (http://creativecommons.org/licenses/by/4.0/), which permits unrestricted use, distribution, and reproduction in any medium, provided you give appropriate credit to the original author(s) and the source, provide a link to the Creative Commons license, and indicate if changes were made.

\section{References}

Allerton C (2014) Statelessness and the lives of the children of migrants in Sabah, East Malaysia. Tilburg Law Rev 19:26-34

Allerton C (2017) Contested statelessness in Sabah, Malaysia: irregularity and the politics of recognition. J Immigr Refug Stud 15(3):250-268

Amnesty International (2017) Forced back into danger: asylum seekers return from Europe to Afghanistan. https://www.amnesty.org/download/Documents/ASA1168662017ENGLISH.PDF. Accessed 2 Aug 2018

Anderson D (2016) Citizenship removal resulting in statelessness. https://assets.publishing.servi ce.gov.uk/government/uploads/system/uploads/attachment_data/file/518120/David_Anderson_ QC_-_CITIZENSHIP_REMOVAL__web_.pdf. Accessed 2 Aug 2018

Arendt H (1958) The origins of totalitarianism, 2nd edn. Meridan Books, New York

Bauböck R (2015) Morphing the demos into the right shape. Normative principles for enfranchising resident aliens and expatriate citizens. Democratization 22(5):820-839. https://doi. org/10.1080/13510347.2014.988146

Bauböck R (2017) Democratic inclusion. Manchester University Press, Manchester

Bauböck R, Paskalev V (2015) Cutting genuine links: a normative analysis of citizenship deprivation. Georgetown Immigr Law J 30:47-104

Bianchini K (2018) Protecting stateless persons. Brill Nijhoff, Leiden

Carens J (2013) The ethics of immigration. Oxford University Press, Oxford

ECOWAS (2017) West Africa on path to become the first region in the world to adopt a plan of action to end statelessness. http://www.ecowas.int/west-africa-on-path-to-become-the-first-region-inthe-world-to-adopt-a-plan-of-action-to-end-statelessness/. Accessed 2 Aug 2018

Gibney MJ (2013) Should citizenship be conditional? The ethics of denationalization. J Polit 75:646-658

Gibney MJ (2014) The deprivation of citizenship in the United Kingdom: a brief history. J Immigr Asylum Natly Law 28:326-335

Gibney MJ (2017) Denationalization. In: Shachar A et al (eds) The Oxford handbook of citizenship. Oxford University Press, Oxford, pp 358-383

Goldston JA (2006) Holes in the rights framework: racial discrimination, citizenship, and the rights of noncitizens. Ethics Int Aff 20:321-347

Howard DM (2017) Analyzing the causes of statelessness in Syrian refugee children. Texas Int Law J 52:281-312

IACHR (2015) Situation of human rights in Dominican Republic. http://www.oas.org/en/iachr/reports/ pdfs/DominicanRepublic-2015.pdf. Accessed 2 Aug 2018

Institute on Statelessness and Inclusion (ISI) (2014) The world's stateless. http://www.institutesi.org/ worldsstateless.pdf. Accessed 2 Aug 2018

Institute on Statelessness and Inclusion (ISI) (2018). Causes of statelessness. http://www.institutesi.org/ world/causes.php. Accessed 5 Oct 2018

Khalid S (2018) As Assam counts its citizens, Muslims fear they may be left out. https://www.aljazeera. com/indepth/features/assam-counts-citizens-muslims-fear-left-180530080633948.html. Accessed 23 Jul 2018

Laborde C, Ronzoni M (2016) What is a free state? Republican internationalism and globalisation. Polit Stud 64:279-296

Macklin A (2014) Citizenship revocation, the privilege to have rights and the production of the alien. Queen's Law J 40:1-54

Macklin A (2015) Kick-off contribution. In: Macklin A, Bauböck R (eds) The return of banishment: do the new denationalisation policies weaken citizenship? EUI Working Papers. http://cadmus.eui.eu/ bitstream/handle/1814/34617/RSCAS_2015_14.pdf?sequence=1. Accessed 2 Aug 2018 
Manby B (2009) Struggles for citizenship in Africa. Zed Books, London

McGuinness T, Gower M (2017) Deprivation of British citizenship and withdrawal of passport facilities. House of Commons Library Briefing Paper no. 06820. http://researchbriefings.parliament.uk/Resea rchBriefing/Summary/SN06820. Accessed 2 Aug 2018

Sardelic J (2015) Romani minorities and uneven citizenship access in the post-Yugoslav space. Ethnopolitics 14(2):159-179

Shachar A (2009) The birthright lottery. Harvard University Press, Cambridge

Simmons BA (2009) Mobilizing for human rights: international law in domestic politics. Cambridge University Press, Cambridge

UNHCR (2010) Expert meeting - the concept of stateless persons under international law ('Prato conclusions'). http://www.refworld.org/docid/4ca1ae002.html. Accessed 2 Aug 2018

UNHCR (2017) Statelessness and the Rohingya crisis. http://www.refworld.org/docid/5a05b4664.html. Accessed 31 Jul 2018

UNICEF (2017a) Birth registration. https://data.unicef.org/topic/child-protection/birth-registration/. Accessed 2 Aug 2018

UNICEF (2017b) A snapshot of civil registration in sub-Saharan Africa. https://data.unicef.org/resources/ snapshot-civil-registration-sub-saharan-africa/. Accessed 2 Aug 2018

Van Waas L (2009) Nationality matters: statelessness under international law. Intersentia, Antwerp

Young S (2017) In our backyard: the Caribbean's statelessness and refugee crisis. https://www.brookings. edu/blog/order-from-chaos/2017/06/20/in-our-backyard-the-caribbeans-statelessness-and-refugeecrisis/. Accessed 2 Aug 2018 